\title{
Inheritance of the genetic construct for RNA- silencing of the $y$-kafirin gene (gKAF1) in the progeny of transgenic sorghum plants
}

\author{
Nataly Borisenko*, Lev Elkonin, and Odyssey Kenzhegulov \\ Federal Centre of Agriculture Research of the South-East Region, 410010, 7, Tulaikov st., Saratov, \\ Russian Federation
}

\begin{abstract}
Sorghum is one of the most important cereal crops in drought regions of the Globe. However, a number of constrains, such as poor nutritional value compared to other cereals, which is caused by resistance of its grain storage proteins (kafirins) to protease digestion, makes it less popular. The use of modern genetic technologies, such as RNA interference, opens up prospects for solving this problem. In this paper, we describe the inheritance of the genetic construct for RNAi silencing of the $\gamma$-kafirin gene (gKAF1) in the progeny of the mutant Avans-1/18, that we obtained previously by Agrobacterium-mediated genetic transformation of immature embryos of commercial cv. Avans. Inheritance of the genetic construct was traced by PCR-analysis to the nos-promoter governing expression of the marker gene bar and to the ubil-intron, which is part of the genetic construct for silencing. It was found that the genetic construct inherited in $T_{1}$ and $T_{2}$ generations of the mutant grown both in the growth chamber and in the field plot, and in the $\mathrm{F}_{1}$ hybrids of the mutant with CMS-lines A2 KVV-181, A2 KVV-114, A2 O-1237, and fertile lines Volzhskoe-4v, Volzhskoe-615, O-1237. The studied plants from $\mathrm{T}_{1}$ and $\mathrm{T}_{2}$ generations had significantly higher in vitro protein digestibility than original non-transgenic cv. Avans. The vitreous endosperm in these plants was reduced either completely or manifested a faint layer. These data demonstrated that genetic construct for gKAF1 silencing was not only stably integrated in genome of the mutant plants but also expressed and improved the digestibility of endosperm proteins. In addition, in $\mathrm{T}_{1}$ progeny we found the plant, PCR positive for nos-promoter but PCRnegative for ubil-intron, that had vitreous endosperm and was characterized by poor in vitro protein digestibility. These data are an example of instability of the genetic construct for RNAi-silencing in genome of some transgenic plants; they show close correlation of the floury endosperm type and high in vitro protein digestibility.
\end{abstract}

\section{Introduction}

One of the most important areas of plant biotechnology is improving the nutritional properties of food and feed crops. Sorghum, like many other cereals, is important in

* Corresponding author: borisencko-n.v@yandex.ru 
considering it as a food source for large number of people. However, nutritional as well as forage value of sorghum grain are significantly restricted because of resistance of its storage proteins - kafirins - to protease digestion [1-4]. It is believed that $\gamma$-kafirin plays an important role in the poor digestibility of kafirins by proteases [5] because it is abundant in cysteine capable to form intra- and intermolecular S-S bonds that results in formation of kafirin oligo- and polymers resistant to protease digestion. In addition, peripheral disposition of $\gamma$-kafirin within the protein bodies prevents protease digestion of the main sorghum storage proteins $-\alpha$-kafirins.

Another factor determining poor nutritional value of sorghum grain is the deficiency of essential amino acids, primarily, lysine, that is caused by its low content in the kafirins [68].

The use of modern genetic technologies - RNA interference and CRISPR/Cas genome editing - opens up prospects for solving this problem. There are several reports on improvement of kafirin digestibility and enrichment of sorghum grain with essential amino acids in transgenic lines carrying the genetic constructs for silencing of kafirin genes [912].

Previously, in the grain sorghum cultivar Avans, we have obtained the RNAi-mutant that carried the genetic construct pNRFAFSIL specially designed for RNA-silencing of the $\gamma$-kafirin gene (gKAF1) [13]. The mutant was characterized by complete disappearance of the vitreous endosperm layer. SDS-PAGE showed that the mutant had reduced content of kafirins. Analysis of endosperm protein in vitro digestibility showed significantly higher level of this trait compared to the original non-transgenic cultivar (up to $93 \%$ against 57 $62 \%)$.

In this paper, we describe the inheritance of the genetic construct in $T_{1}$ and $T_{2}$ generations as well as in the $\mathrm{F}_{1}$ hybrids of transgenic plants with different sorghum lines.

\section{Methods}

The original mutant with high in vitro endosperm protein digestibility was obtained in experiment on Agrobacterium-mediated genetic transformation of the new commercial variety Avans of Sorghum bicolor (L.) Moench with the A. tumefaciens strain GV3101 that carried pNRKAFSIL binary vector [13]. This vector contains the genetic construct consisted of the fragment of the $\gamma$-kafirin gene (gKAF1, GeneBank accession no. M73688 [14]) in forward and inverted orientation, which was separated by the sequence of the maize ubil-intron [12]. This construct was driven by the $35 \mathrm{~S}$ promoter. Such a construct should suppress the expression of the $\gamma$-kafirin gene using RNA interference. As a selectable marker, this vector contained the bar gene under the control of the nos-promoter.

The original RNAi-mutant, Avans-1/18, was self-pollinated and its progeny was grown in the growth chamber (photoperiod 16 hours day/ 8 hours night; $\mathrm{t}^{\circ} 28^{\circ} \mathrm{C} / 22{ }^{\circ} \mathrm{C}$ ) and in the plot in experimental field of the Federal Centre of Agriculture Research of the South-East Region (Saratov, Russia). To study inheritance of the transgenic construct, the panicles of transgenic plants were carefully bagged by parchment bags before anthesis. In addition, they were crossed as male parents with lines with cytoplasmic male sterility (CMS) A2 KVV-181, A2 KVV-114 and A2 O-1237, and with hand-emasculated panicles of cv. Volzhskoe-4 and Volzhskoe-615 grown in the same experimental field.

To study resistance of transgenic plants to glufosinate ammonium (GA), mature kernels were sterilized with Domestos and $\mathrm{HgCl}_{2}(0.1 \%)$ and were pre-soaked in solution of GA $(2.5 \mathrm{mg} / \mathrm{l})$ for 20 hours. The embryos were removed from pre-soaked kernels and were put in the test-tubes on the agar medium containing MS salts, sucrose $(2 \%)$, vitamins, and filter-sterilized GA $(2.5 \mathrm{mg} / \mathrm{l})$, and were cultured in the light (photoperiod 16 hours day/ 8 hours; $\mathrm{t}^{\circ} 28^{\circ} \mathrm{C}$ ) for 3-4 weeks. Developed plantlets were transferred to the growth chamber. 
To study in vitro protein digestibility, the method of whole-grain flour pepsin treatment, widely practiced in the past few years, was used [1-4]. The flour (20 mg) of transgenic samples and of original non-transgenic cv. Avans was treated with $5 \mathrm{ml}$ of $0.15 \%$ pepsin solution (Sigma-Aldrich, activity: 806 units $/ \mathrm{mg}$ of protein) in a $0.1 \mathrm{M}$ potassium phosphate buffer $(\mathrm{pH} 2.0)$ for $120 \mathrm{~min}$ at $37^{\circ} \mathrm{C}$ with repeated shaking. The control samples were incubated in potassium phosphate buffer without pepsin addition under the same conditions.

For quantitative estimation of protein digestibility, the efficient and informative electrophoresis-based protein assay was used $[15,3,4]$. For this purpose, the digested and control samples were centrifuged at $13000 \mathrm{rpm}$ and the pellet was incubated with a sample buffer $(0.0625 \mathrm{M}$ Tris $\cdot \mathrm{HCl}, \mathrm{pH} 6.8)$ under reducing conditions (2\% SDS, 5\% 2 mercaptoethanol) at $100^{\circ} \mathrm{C}$ for $90 \mathrm{~s}$. The samples were centrifuged at $13000 \mathrm{rpm}$ and subjected to SDS-PAGE. SDS-PAGE was carried out in $13.0 \%(\mathrm{w} / \mathrm{v})$ PAG according to modified Laemmli method, in each lane, $20.7 \mu \mathrm{L}$ of extract was loaded. Separation was monitored by using Protein Molecular Weight Markers (14-116 kDa) (Thermo Scientific). The gels were stained with Coomassie Brilliant Blue R-250. After electrophoresis, the gels were scanned with an Epson Perfection V700 Photo scanner. The amount of protein was quantified with the Scangel program (Dr. A.F. Ravich, Agricultural Research Institute of South-East Region, Saratov, Russian Federation). The digestibility value was counted as the percent ratio of the difference between protein volume in the control sample and in digested sample to the protein volume in the control sample.

The presence of the genetic construct for RNAi-silencing was tested by PCR analysis with primers amplified the 201-bp fragment of the nos-promoter $\left(F \quad\left(5^{\prime} \rightarrow 3^{\prime}\right)\right.$ : tgagactctaattggataccgaggg; $\mathrm{R}\left(5^{`} \rightarrow 3^{\prime}\right)$ : tttggaactgacagaaccgcaac) and the 588-bp fragment of the maize ubil-intron (F: tgtcttggttgtgatgatgtggtc; R: gcgtatgaaggcagggctaaa). The reaction mixture contained x50 PCR buffer, $2.5 \mathrm{mM} \mathrm{MgCl} 2,0.2 \mathrm{mM} \mathrm{dNTP}, 0.05 \mathrm{U} / \mu \mathrm{l}$ Syntaq DNA polymerase, $0.6 \mathrm{pmol}$ of each primer. The total volume of the reaction mixture was $25 \mu l$. The PCR reaction was carried out using a MasterCycler DNA amplifier (Eppendorf, Germany). PCR conditions were as follows: for the nos-promoter $95^{\circ} \mathrm{C}(2$ $\mathrm{min})$, then 40 cycles $\left[95^{\circ} \mathrm{C}(30 \mathrm{sec}), 64^{\circ}(30 \mathrm{sec}), 72^{\circ}(1 \mathrm{~min} 10 \mathrm{sec})\right]$, and $72^{\circ}(7 \mathrm{~min})$. For the ubil-intron, $95^{\circ} \mathrm{C}(2 \mathrm{~min})$, then 40 cycles $\left[95^{\circ} \mathrm{C}(1 \mathrm{~min}), 56^{\circ}(1 \mathrm{~min}), 72^{\circ}(1 \mathrm{~min} 30\right.$ $\mathrm{sec})$ ], and $72^{\circ}(10 \mathrm{~min})$. Amplified fragments were visualized by $2.6 \%$ and $1.3 \%$ agarose gel electrophoresis, respectively.

\section{Results}

15 out of 16 tested $T_{1}$ plants grown in the growth chamber and in the field plot, were positive for both nos-promoter and ubil-intron (Fig. 1, Table 1). These data confirm the transgenic nature of the original mutant Avans-1/18. One plant (\#6) was negative for both nos-promoter and ubil-intron. Such a ratio of transgenic vs. non-transgenic plants resembled 15:1 segregation ratio suggesting integration of two copies of the genetic construct for RNA-silencing in the genome of original mutant Avans-1/18.

Table 1. Results of PCR-analysis of self-pollinated progeny of the RNAi mutant Avans-1/18 and its $F_{1}$ hybrids with different sorghum lines using primers to the fragments of nos-promoter and ubil-intron.

\begin{tabular}{|c|c|c|c|c|c|c|}
\hline $\begin{array}{c}\text { Generation / Hybrid } \\
\text { combination }\end{array}$ & \multicolumn{3}{|c|}{ Nos-promoter } & \multicolumn{3}{c|}{ Ubi1-intron } \\
\cline { 2 - 7 } & Total & $\begin{array}{c}\text { PCR } \\
+\end{array}$ & PCR - & Total & PCR + & PCR - \\
\hline \multicolumn{7}{|c|}{ Without selection to GA } \\
\hline $\mathrm{T}_{1}$ grown in the growth chamber & 12 & 11 & 1 & 12 & 11 & 1 \\
\hline
\end{tabular}




\begin{tabular}{|l|l|l|l|l|l|l|}
\hline $\mathrm{T}_{1}$ grown in field plot (\#190) & 4 & 4 & 0 & 4 & 3 & 1 \\
\hline $\mathrm{T}_{2}$ (from $\mathrm{T}_{1}$ plant \#3) & 18 & 18 & 0 & 18 & 18 & 0 \\
\hline $\mathrm{A} 2 \mathrm{KVV}-181 \times \mathrm{T}_{1} 190-2$ & 12 & 10 & 2 & 12 & 7 & 5 \\
\hline $\mathrm{A} 2 \mathrm{KVV}-114 \times \mathrm{T}_{1} 190-1$ & 11 & 11 & 0 & 12 & 6 & 6 \\
\hline $\mathrm{A} 2 \mathrm{O}-1237 \times \mathrm{T}_{1} 190-1$ & 12 & 9 & 3 & 12 & 8 & 4 \\
\hline \multicolumn{7}{|}{ Selected on the medium with $2.5 \mathrm{mg} / \mathrm{l} \mathrm{GA}$} \\
\hline Volzhskoe 4B $\times \mathrm{T}_{1} 190-2$ & 3 & 2 & 1 & 3 & 2 & 1 \\
\hline Volzhskoe 615 $\times \mathrm{T}_{1} 190-2$ & 3 & 3 & 0 & 3 & 3 & 0 \\
\hline O-1237/T $190-4$ & 2 & 2 & 0 & 2 & 2 & 0 \\
\hline
\end{tabular}
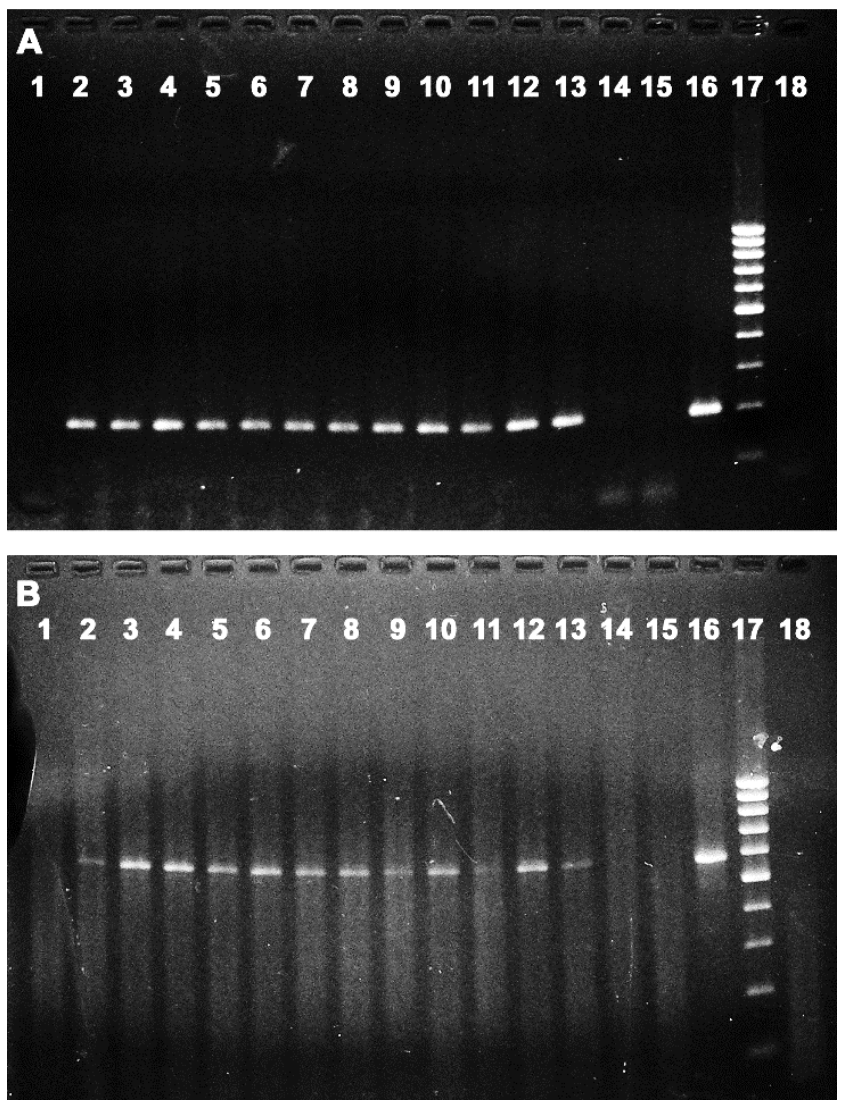

Fig. 1. PCR analysis of plants from the RNAi-mutant Avans-1/18 ( $\mathrm{T}_{1}$ generation) with primers to the fragments of nos-promoter (A) and ubi1-intron (B). 1 - original non-transgenic cv. Avans; 2-13 different plants from $T_{1}$ generation; 14,15 - plants from another experiment; 16 - positive control (GV3101/pNRKAFSIL); 17 - DNA markers; 18 - negative control (no DNA).

In the $T_{2}$ family obtained by self-pollination of $T_{1}$ plant \#3, no segregation for nospromoter or ubil-intron was found. All examined $18 \mathrm{~T}_{2}$ plants were PCR-positive for both nos-promoter and ubil-intron (Table 1) suggesting homozygous nature of this $\mathrm{T}_{1}$ plant and stable integration of the genetic construct for RNA-silencing. This conclusion was confirmed by analysis of in vitro endosperm protein digestibility in these mutants and their endosperm texture. The studied plants from $\mathrm{T}_{1}$ and $\mathrm{T}_{2}$ generations had significantly higher protein digestibility than original non-transgenic cv. Avans (Table 2; Fig. 2). The vitreous endosperm in these plants was reduced either completely or manifested a faint layer (Fig. 3 ). These data demonstrated that genetic construct for gKAF1 silencing was not only stably 
integrated in genome of the mutant plants but also expressed and improved the digestibility of endosperm proteins.

Table 2. In vitro protein digestibility of endosperm proteins in some plants from $\mathrm{T}_{1}$ and $\mathrm{T}_{2}$ generations.

\begin{tabular}{|c|c|c|}
\hline Plant № & Growing conditions & $\begin{array}{c}\text { Digestibility }^{1,2}, \\
\%\end{array}$ \\
\hline $\mathrm{T}_{1} \# 1$ & Growth chamber & $90.48 \mathrm{bc}$ \\
\hline $\mathrm{T}_{1} \# 2$ & Growth chamber & $92.43 c$ \\
\hline $\mathrm{T}_{1} \# 3$ & Growth chamber & $85.06 \mathrm{~b}$ \\
\hline $\mathrm{T}_{1} \# 7$ & Growth chamber & $90.01 \mathrm{bc}$ \\
\hline $\mathrm{T}_{1} \# 10$ & Growth chamber & $88.90 \mathrm{bc}$ \\
\hline cv. Avans, non-transgenic control & Growth chamber & $71.23 \mathrm{a}$ \\
\hline \multicolumn{2}{|l|}{ 等 } & $21.241 *$ \\
\hline \multicolumn{2}{|c|}{$\mathrm{HCP}_{05}$} & 6.15 \\
\hline $\mathrm{T}_{1} \# 190-4$ & Field plot & $92.2 \mathrm{c}$ \\
\hline $\mathrm{T}_{2} \# 3-5$ & Field plot & $74.7 \mathrm{~b}$ \\
\hline cv. Avans, non-transgenic control & Field plot & $52.3 \mathrm{a}$ \\
\hline \multicolumn{2}{|l|}{ e } & $558.946^{*}$ \\
\hline \multicolumn{2}{|c|}{$\mathrm{HCP}_{05}$} & 5.14 \\
\hline
\end{tabular}

${ }^{1}$ Mean from two replications; ${ }^{2}$ Data for the samples grown in the same growth conditions denoted by different letters, differ at $p<0.05$ according to Duncan's Multiple Range Test; *significant at $p<0.05$.

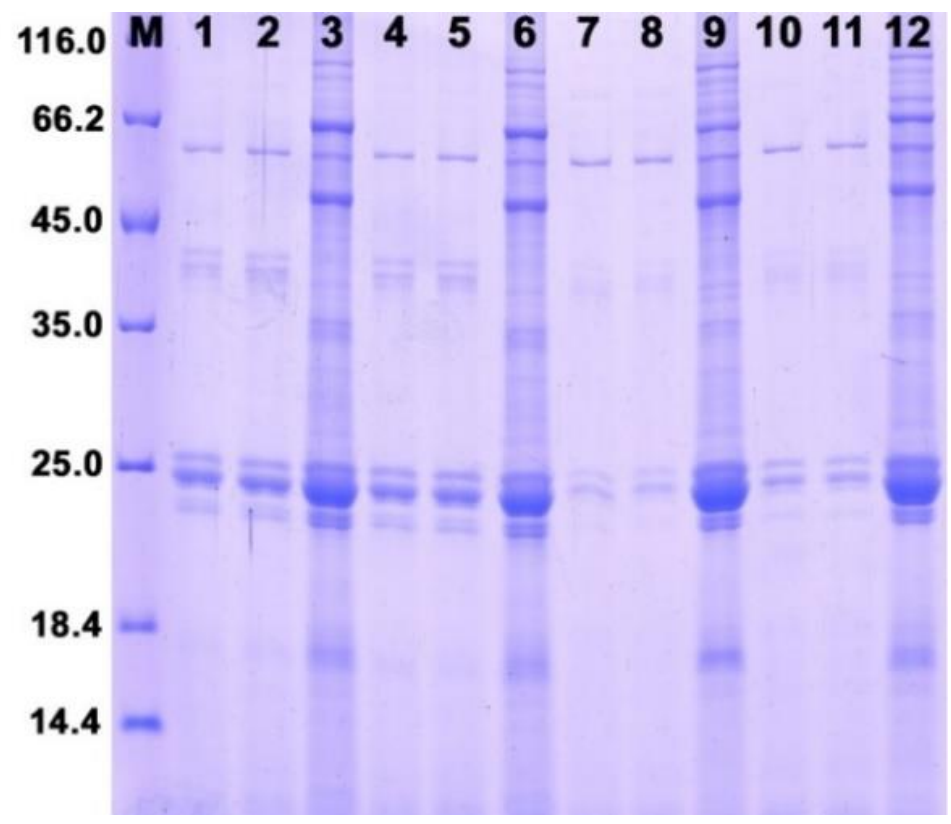

Fig. 2. Electrophoretic spectra (SDS-PAGE) of proteins from the flour of original non-transgenic sorghum cv. Avans (1-6), transgenic plants from $\mathrm{T}_{1}$ generation grown in the field plot (\#190-4, lanes 7-9) and from $\mathrm{T}_{2}$ generation grown in the growth chamber (\#3-5, lanes 10-12). $\mathrm{M}$ - molecular mass markers $(\mathrm{kDa}) ; 1,2,4,5,7,8,10,11$ - spectra after pepsin digestion; $3,6,9,12$ - spectra from the same extracts without pepsin digestion (control). 


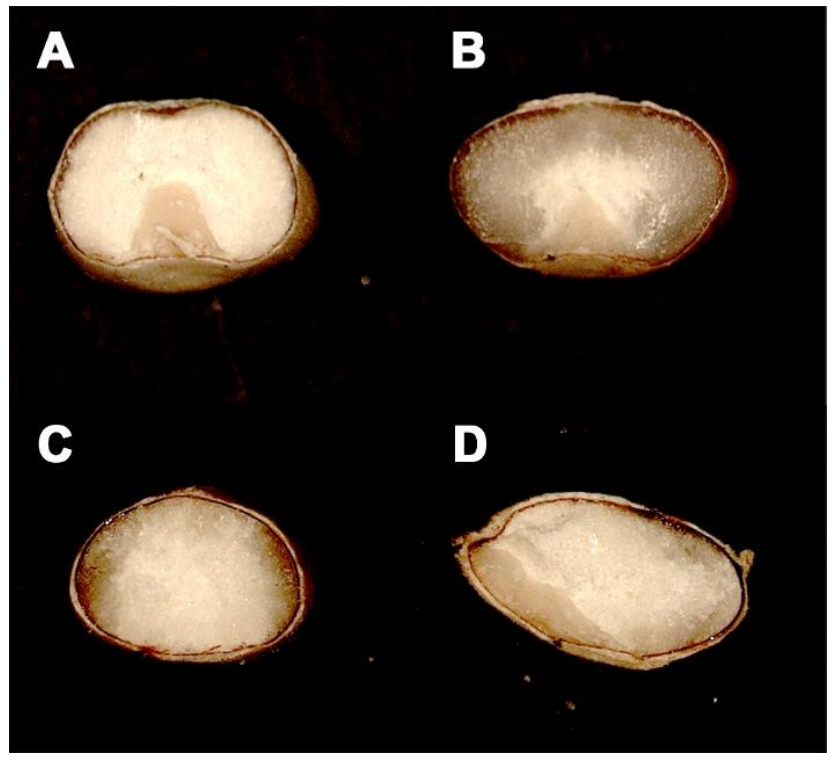

Fig. 3. Cross sections of the kernels of plants from $T_{1}(\# 190-4)$ and $T_{2}$ generations (\#3-5) carrying the genetic construct for the $\gamma$-kafirin gene silencing $(\mathrm{A}, \mathrm{C}, \mathrm{D})$, and original non-transgenic cv. Avans (B). Note thick vitreous endosperm layer in kernel of cv. Avans (B) and total absence of vitreous endosperm (A) or faint or blurred vitreous layer in transgenic kernels of plant \#3-5 (C, D).
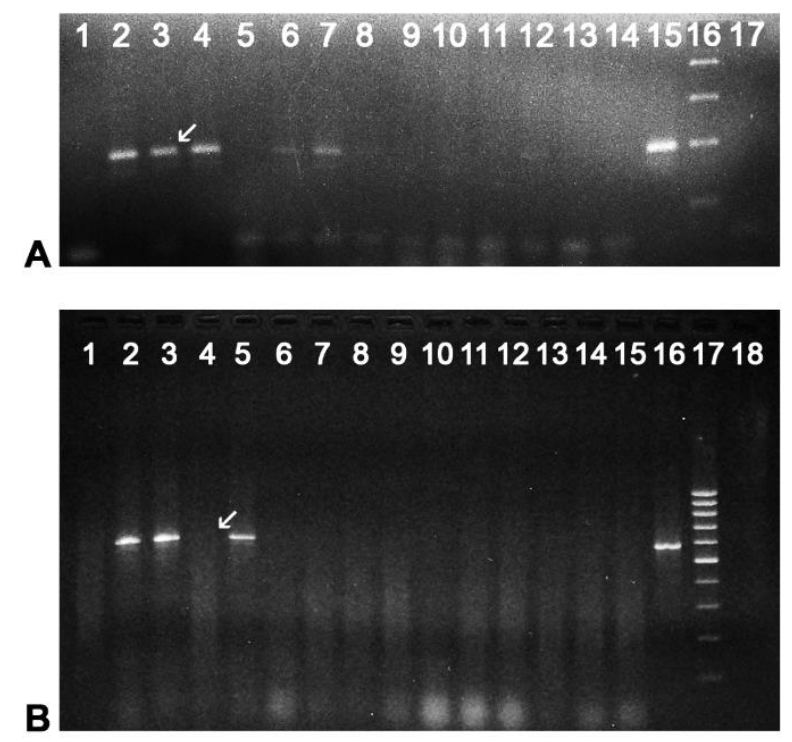

Fig 4. PCR analysis of plants from $T_{1}$ generation grown in the field plot (\#190/20), with primers to the nos-promoter (A) and ubil-intron (B). 1 - Original non-transgenic cv. Avans; 2-4 (A) and 2-5 (B) - individual T 1 plants (A: \#190-2, \#190-3, \#190-4; B: \#190-1, \#190-2, \#190-3, \#190-4, respectively); 5-14(A) and 6-15 (B) - Plants from another experiment; 15 (A), 16 (B) - positive control (GV3101/pNRKAFSIL); 16 (A), 17 (B) - DNA markers; 17 (A), 18 (B) - Negative control (no DNA). The arrows mark the products of DNA amplification in plant \#3.

Remarkably, all studied $\mathrm{T}_{1}$ plants grown in the field plot were transgenic because they carried the nos-promoter driving the expression of the marker gene bar (Fig. 4A). However, 
one of these plants (\#190-3) was PCR-negative for the ubil-intron, which is a part of the genetic construct for silencing (Fig 4B). All kernels developed in the panicle of plant \#3 had the vitreous type of endosperm, characteristic to the original non-transgenic cultivar, while in the panicles of other plants, in which the ubil-intron was present, the kernels had a floury type of endosperm, characteristic for transgenic plants with $\gamma$-kafirin silencing. In addition, endosperm proteins form the kernels of the plant \#190-3 had low protein digestibility characteristic to the original non-transgenic cultivar (Fig. 5; Table 2). Therefore, these data demonstrate instability of introduced genetic construct for RNAisilencing taking place in genome of some transgenic plants. In addition, these data showed close correlation of the floury endosperm type and high in vitro protein digestibility.

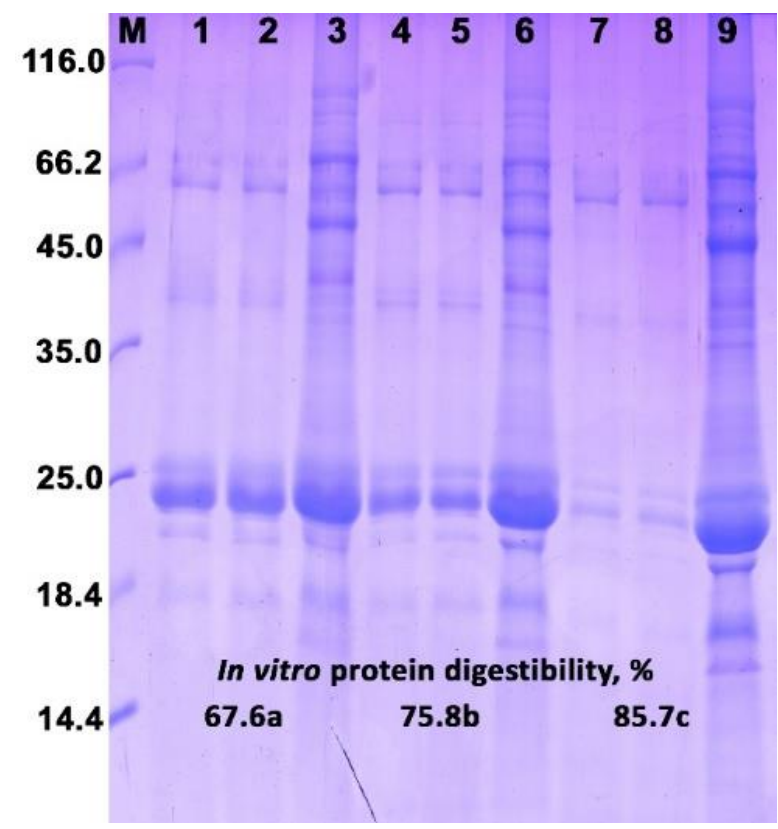

Fig. 5. Electrophoretic spectra (SDS-PAGE) of proteins from the flour of original non-transgenic sorghum cv. Avans (1-3), transgenic plants from $T_{1}$ generation grown in the field plot \#190-3 (lanes 4-6) and \#190-4 (lanes 7-9). M - molecular mass markers (kDa); 1, 2, 4, 5, 7, 8 - spectra after pepsin digestion; 3, 6, 9 - spectra from the same extracts without pepsin digestion (control). In vitro protein digestibility values marked with different letters are significantly different at $\mathrm{p}<0.05$.

PCR-positive $T_{1}$ plants \#190-1 and \#190-2 segregated for endosperm type (Table 3). The kernels with floury endosperm predominated, while in some kernels faint layer or patches of vitreous endosperm, or normally developed vitreous endosperm were observed. These data suggested heterozygous nature of plants \#190-1 and \#190-2. The ratio of kernels with floury and vitreous endosperm suggested digenic ratio. No segregation for endosperm type was observed in the kernels set on the panicle of \#190-4 plant that pointed on its homozygous nature. 
Table 3. Characterization of the endosperm type in the progeny of transgenic plants from $T_{1}$ generation carrying the genetic construct for the $\gamma$-kafirin gene (gKAF1) silencing.

\begin{tabular}{|c|c|c|c|c|}
\hline \multirow[b]{2}{*}{ Ti plant No. } & \multirow[b]{2}{*}{$\begin{array}{c}1000 \text { grain } \\
\text { weight, } g\end{array}$} & \multicolumn{3}{|c|}{ Endosperm type, number of kernels } \\
\hline & & Floury & $\begin{array}{c}\text { Faint or blurred } \\
\text { vitreous layer }\end{array}$ & $\begin{array}{c}\text { Normal } \\
\text { vitreous } \\
\text { layer }\end{array}$ \\
\hline 190-1 (nos+, ubi1+) & 29.4 & 40 & - & 4 \\
\hline 190-2 (nos+, ubi1+) & 25.2 & 27 & 12 & 8 \\
\hline 190-3 (nos+, ubi1-) & 36.4 & - & - & 16 \\
\hline 190-4 (nos+, ubil+) & 28.8 & 29 & - & - \\
\hline cv. Avans (nos-, ubi1-) & 34.5 & - & - & 15 \\
\hline
\end{tabular}

PCR-positive for ubil-intron plants \#190-1 and \#190-2 were crossed with CMS-lines A2 KVV-181, A2 KVV-114, A2 O-1237, and with hand-emasculated panicles of fertile lines Volzhskoe-4v and Volzhskoe-615. The progenies of the $F_{1}$ hybrids as well as selfpollinated progeny of the paternal nos-promoter positive $\mathrm{T}_{1}$ plants were tested for tolerance to the growth on the medium containing glufosinate ammonium, the selective agent to be degraded by the marker bar gene.

All plants from $T_{2}$ family derived from $\# 190-4$ were tolerant to GA as was expected in the case of bar gene expression. These data suggest that parental $\mathrm{T}_{1}$ plant was homozygous. In the progenies \#190-1 and \#190-2 both resistant and sensitive individuals were observed (Table 4); their ratio corresponded to $15: 1$ segregation. Such segregation pointed that $T_{1}$ plants \#190-1 and \#190-2 were heterozygous and carried possibly two copies of the genetic construct NRKAFSIL. Therefore, among $F_{1}$ hybrids one should expect both resistant and sensitive to GA plants that was really observed in our experiments (Table 4). Remarkably, in each studied hybrid progeny the number of resistant and sensitive plants was the same, 18 and 12, respectively. In case of digenic analyzing cross, the ratio of resistant and sensitive plants should be 3:1. However, observed ratio did not fit this model (Table 4). Nevertheless, it fitted to 2:1 ratio that might be observed in the case of silencing of one gene copy.

Table 4. Segregation for resistance to glufosinate ammonium $(\mathrm{GA}, 2.5 \mathrm{mg} / \mathrm{l})$ in the progeny of $\mathrm{T}_{1}$ plants \#190-1 and \#190-2 and their $\mathrm{F}_{1}$ hybrids with different CMS-lines.

\begin{tabular}{|l|c|c|}
\hline \multirow{2}{*}{ Progeny / Hybrid combination } & \multicolumn{2}{c|}{$\begin{array}{c}\text { Number of seedlings on MS medium } \\
\text { with GA (2.5 mg/l) }\end{array}$} \\
\cline { 2 - 3 } & resistant & sensitive \\
\hline $\mathrm{T}_{2} 190-4$ & 30 & 0 \\
\hline $\mathrm{T}_{2} 190-1$ & 26 & 4 \\
\hline $\mathrm{T}_{2} 190-2$ & 28 & 2 \\
\hline Total for 190-1 and 190-2 families & 54 & 6 \\
\hline \multicolumn{2}{|c|}{$\chi^{2} 15: 1=1.4400 .10<\mathrm{P}<0.25$} \\
\hline A2 KVV-181 $\times \mathrm{T}_{1} 190-2$ & 18 & 12 \\
\hline A2 KVV-114 $\times \mathrm{T}_{1} 190-1$ & 18 & 12 \\
\hline A2 O-1237 $\times \mathrm{T}_{1} 190-1$ & 18 & 12 \\
\hline Total for hybrid families & 54 & 36 \\
\hline \multicolumn{2}{|c|}{$\chi^{2} 3: 1=10.800 \mathrm{P}<0.05 ; \chi^{2} 2: 1=1.8000 .10<\mathrm{P}<0.25$} \\
\hline
\end{tabular}

PCR analysis of the $F_{1}$ hybrids from crosses of \#190-1 plant with fertile lines Volzhskoe-4v and Volzhskoe-615, which have been selected on GA-containing medium, confirmed that selected plants resistant to GA indeed were transgenic and contained both nos-promoter and ubil-intron nucleotide sequences (Table 1). 


\section{Discussion}

RNA interference technology is a powerful tool for down-regulation of plant gene expression including the genes involved in the synthesis of the seed storage proteins [13, 16]. Previously published reports indicate that this approach allows the creation of sorghum lines with a reduced content of kafirins, which leads to improved digestibility of endosperm proteins by proteases and the synthesis of other proteins with higher content of essential amino acids [9-12].

The results of our studies, presented above, show that the progeny of the RNAi mutant with improved digestibility of endosperm proteins that we had obtained early [21], stably inherits the introduced genetic construct in $T_{1}$ and $T_{2}$ generations and in crosses with other lines of grain sorghum. The observed ratio of PCR-positive and PCR-negative plants in $\mathrm{T}_{1}$ generation resembled 15:1 segregation that suggested integration of two copies of the genetic construct for RNA-silencing in the genome of original mutant Avans-1/18. However, these data should by confirmed by Southern-blot hybridization, and before this analysis no definite conclusion can be made.

Obviously, as a result of expression of the genetic construct for RNA-silencing, PCRpositive for ubil-intron plants had modified endosperm type with strongly reduced vitreous layer. Such modification of endosperm type is common in transgenic sorghum plants with reduced synthesis of $\gamma$-kafirin [9-12]. Another consequence of expression of the genetic construct for the $\gamma$-kafirin gene silencing is a significant improvement of in vitro digestibility of proteins extracted from the flour of transgenic kernels that has been also reported in previous publications [9-12]. It is noteworthy that the differences from original non-transgenic cultivar Avans for in vitro protein digestibility were more prominent in field conditions than in the growth chamber (Table 2) since in vitro digestibility of endosperm protein in kernels of this cultivar ripened in the growth chamber is much higher than in kernels ripened in field conditions. In the available literature, we did not find a similar fact of the influence of plant growing conditions on the digestibility of storage proteins in normal non-transgenic cultivars. At the same time, this fact contradicts to our previous observations on transgenic plants of $\mathrm{cv}$. Zheltozernoe 10 carrying the same genetic construct for $\gamma$-kafirin gene silencing, in which the differences in the digestibility of endosperm proteins, in comparison with the original non-transgenic cultivar, were much less noticeable when grown in field conditions than when grown in a greenhouse [17].

In addition, in this paper, we documented the real case of instability of the genetic construct for RNA-silencing in genome of the transgenic plants: one of the studied $T_{1}$ plants (\#190-3) was PCR-positive for nos-promoter but negative for ubil-intron. Perhaps, the construct for silencing sometimes is subjected to the destruction and the ubil-intron might be cut out of the construct. The kernels set on this plant had thick vitreous endosperm layer and were characterized by poor in vitro protein digestibility that should be expected in the case of the absence of functioning genetic construct for $\gamma$-kafirin gene silencing. These data confirm well-known correlation of high digestibility of kafirins and floury endosperm in such mutants [18] that reduces the commercial value of the created transgenic lines, since floury endosperm reduces the mechanical strength of the kernels and increases their susceptibility to fungal microflora.

Remarkably, such a correlation was also found in $T_{2}$ plant \#3-5, which had traces of vitreous endosperm in the kernels (Fig. $3 \mathrm{C}, \mathrm{D}$ ) and lower in vitro protein digestibility significantly differing both from the transgenic kernels with floury endosperm (\#190-4) and the kernels of original non-transgenic line (Table 2). Assuming that this plant was PCRpositive for ubil-intron, the observed variation in expression of endosperm traits might be the consequence of silencing of introduced genetic construct, such an example of "silencing silencer". 
Also noteworthy is a high frequency of transgenic (PCR-positive for the nos-promoter) plants among $F_{1}$ hybrids (Table 1). In case of monogenic inheritance, 1:1 ratio of PCRpositive and PCR-negative plants should be observed among $F_{1}$ hybrids. Even if we assume that the paternal transgenic plants carried two copies of the genetic construct, that follows from PCR analysis of $T_{1}$ progeny as well as from the results of selection for resistance to GA in the self-pollinated progeny of paternal $\mathrm{T}_{1}$ plants (Table 4 ), then $25 \%$ of individuals among $F_{1}$ hybrids should be PCR-negative (3:1 in the analyzing cross). However, in fact, such a ratio was observed only in the hybrid combination A2 O-1237 $\times \mathrm{T}_{1} 190$-1, while in the hybrid combination A2 KVV-114 $\times \mathrm{T}_{1}$ 190-1 there were no PCR-negative plants, and in the hybrid combination A2 KVV-181 $\times \mathrm{T}_{1}$ 190-2 there were only few such plants. The reasons for this phenomenon are not clear and deserve further investigations. Notably, several plants in each hybrid combination were PCR-positive for nos-promoter but were PCR-negative for ubil-intron (Table 1). These data are possibly explained by the destruction of the genetic construct in the genome of hybrid plants and excision of the ubi1intron nucleotide sequence. But it's still too early to make unambiguous conclusions on this issue, until additional research is applied. Nevertheless, it is clear that the genetic construct for silencing can be introduced into other sorghum genotypes through conventional crosses.

\section{Conclusions}

The genetic construct for $\gamma$-kafirin gene (gKAF1) silencing introduced in genome of the sorghum mutant Avans-1/18, inherited in $T_{1}$ and $T_{2}$ generation and in its $F_{1}$ hybrids with different cultivars and CMS-lines. The lines carrying the genetic construct for gKAF1 silencing in homozygous condition were identified. Plants from $T_{1}$ and $T_{2}$ generation, PCR positive for maize ubil-intron 588 bp sequence, which is a part of the genetic construct for gKAF1 silencing, have a floury endosperm type and improved in vitro protein digestibility of endosperm proteins. The $588 \mathrm{bp}$ ubil-intron sequence may be used as a molecular marker in screening plants with high in vitro digestibility of endosperm proteins in hybridization of the Avans-1/18 mutant with different sorghum cultivars. Using selection for tolerance to glufosinate ammonium in the hybrid progeny obtained on the basis of the Avans-1/18 mutant, it is possible to select plants carrying the genetic construct for gKAF1 silencing.

The work was funded in part by the Russian Foundation for Basic Research, grant 19-016-00117.

\section{References}

1. M.P. Oria, B.R. Hamaker, J.M. Shull, J Agric. Food Chem., 43 (1995)

A. Nunes, I. Correia, A. Barros, I. Delgadillo, J. Agric. Food Chem., 52 (2004)

2. J.H. Wong, T. Lau, N. Cai, J. Singh, J.F. Pedersen, W.H. Vensel, W.J. Hurkman, J.D. Wilson, P.G. Lemaux, B.B. Buchanan, J. Cereal Sci., 49 (2009)

3. L.A. Elkonin, J.V. Italianskaya, I.Yu. Fadeeva, V.V. Bychkova, V.V. Kozhemyakin, Euphytica, 193 (2013)

4. M.P. Oria M.P., B.R. Hamaker B.R., J.D. Axtell, C.P. Huang, Proc. Natl. Acad. Sci. USA, 97 (2000)

5. P.S. Belton, I. Delgadillo, N.G. Halford, P.R. Shewry, J. Cereal Sci., 44 (2006)

6. N.J. De Mesa-Stonestreet, S. Alavi, S.R. Bean, J. Food Sci.,75 (2010)

7. E.C. Henley, J.R.N. Taylor, S.D. Obukosia, Advances in Food and Nutrition Research, 60 (Burlington, Academic Press, 2010) 
8. L.S. da Silva, J. Taylor, J.R. Taylor, J. Agric. Food Chem., 59 (2011)

9. T. Kumar, I. Dweikat, S. Sato, Z. Ge, N. Nersesian, T. Elthon, S. Bean, B.P. Ioerger, M. Tiley, T. Clemente, Plant Biotechnol. J., 10 (2012)

10. A.W. Grootboom, N.L. Mkhonza, Z. Mbambo, M.M. O'Kennedy, L.S. da Silva, J. Taylor, J.R.N. Taylor, R. Chikwamba, L. Mehlo, Plant Cell Rep., 33 (2014)

11. L.A. Elkonin, J.V. Italianskaya, I.V. Domanina, N.Y. Selivanov, A.L. Rakitin, N.V. Ravin, Russ. J. Plant Physiol., 63 (2016)

12. L.A. Elkonin, V.M. Panin, O.A. Kenzhegulov, S.Kh. Sarsenova, Grain and Seed Proteins Functionality (Intech Open Ltd., London, 2021)

13. E.G. De Barros, K. Takasaki, A.W. Kirleis, B.A. Larkins, Plant Physiol., 97 (1991)

A. Aboubacar, J.D. Axtell, C.P. Huang, B.R. Hamaker, Cereal Chemistry, 78 (2001)

14. Q. Guo, Q. Liu, N.A. Smith, G. Liang, M.B. Wang, Current Genomics, 17 (2016)

15. Л.А. Эльконин, Ю.В. Итальянская, Успехи современного естествознания, 12 (2017)

16. D. Duressa, D. Weerasoriya, S.R. Bean, M. Tilley, T. Tesso, Crop Sci., 58 (2018) 